Etikonomi

Volume 14 (2), Oktober 2015

P-ISSN: 1412-8969; E-ISSN: 2461-0771

Halaman $221-240$

\title{
PERAN PERBANKAN SYARIAH DALAM MENGIMPLEMENTASIKAN KEUANGAN INKLUSIF DI INDONESIA
}

\author{
Novia Nengsih \\ Sekolah Pascasarjana UIN Syarif Hidayatullah Jakarta \\ novianengsih04@yahoo.com
}

\begin{abstract}
.
This study aimed to analyze the role of islamic banks in implementing financial inclusion in Indonesia. Financial inclusion is a process to provide formal financial access for the poor and low income people (unbankable people). This study was designed which approached qualitatively and quantitatively (mixed research). The qualitative data analyzed by using Straruss and Corbin's theory consisted three major steps: open coding, axial coding, and selective coding. Quantitative analyzed by using comparative analysis of financial statements and financial ratio analysis such as CAR, ROA, ROE, NPF, and FDR period of 2010-2014. This study proved that Islamic banking had great potential in implementing financial inclusion, it was indicated by a significant increase in funding and financing since 2010-2014 and results of financial ratio analysis also shows the performance of Islamic banking and financial condition is good.
\end{abstract}

Keywords: Islamic banks; financial inclusion; financial exclusion.

\begin{abstract}
Abstrak.
Penelitian ini bertujuan untuk menganalisis peran perbankan syariah dalam mengimplementasikan financial inclusion di Indonesia. Financial inclusion merupakan proses untuk memberikan akses keuangan formal bagi masyarakat miskin dan perpenghasilan rendah (unbankable people). Penelitian ini menggunakan pendekatan kualitatif dan kuantitatif (mixed research). Analisis data kualitatif menggunakan teknik analisis yang dikembangkan oleh Straruss dan Corbin dengan tiga langkah besar, yaitu open coding, axial coding, dan selective coding. Analisis data kuantitatif menggunakan analisis perbandingan laporan keuangan pada tahun 2010-2014 dan analisis rasio keuangan berupa CAR, ROA, ROE, NPF, dan FDR. Penelitian ini membuktikan bahwa perbankan syariah memiliki potensi besar dalam mengimplementasikan financial inclusion, ditunjukkan dengan pertumbuhan yang signifikan pada funding dan financing tahun 2010-2014 dan hasil analisis rasio keuangan juga menunjukkan kinerja dan kondisi keuangan perbankan syariah baik.
\end{abstract}

Kata Kunci: perbankan syariah; keuangan inklusif; keuangan eksklusif

Diterima: 15 Mei 2015; Direvisi: 10 Juli 2015; Disetujui: 25 Juli 2015

http://journal.uinjkt.ac.id/index.php/etikonomi 


\section{PENDAHULUAN}

Krisis keuangan global yang terjadi tahun 1998, krisis tahun 2008, dan krisis di Eropa tahun 2011, telah membuat industri perbankan Eropa anjlok. Keadaan perekonomian ini membuat kekuatan perekonomian dunia beralih dari Barat ke Timur, khususnya Asia. Saat terjadinya krisis ini, beberapa negara di Asia justru mengalami pertumbuhan.

Jhong Wha Lee (2012) dalam penelitiannya menemukan bahwa negara berkembang di Asia tumbuh pesat selama tiga dekade terakhir terutama karena pertumbuhan yang kuat pada akumulasi modal yang mencapai 6,01 persen pada tahun 2012 dan 6,6 persen pada tahun 2013. Cina, India, dan Indonesia tetap bisa mempertahankan pertumbuhan ekonominya masingmasing dengan kekuatan konsumsi domestik. Salah satu faktor tingginya tingkat konsumsi yang terjadi di Cina, India, dan Indonesia adalah jumlah populasi negara tersebut hampir setengah dari penduduk di dunia, yaitu sekitar 2,8 miliar penduduk atau sekitar 40 persen dari jumlah penduduk dunia.

Xiaoqiang Cheng dan Hans Degryse (2010) mengatakan bahwa pertumbuhan ekonomi yang cukup tinggi salah satunya didukung oleh sektor keuangan, baik perbankan maupun non-bank. Pembangunan sektor perbankan dapat mendorong pertumbuhan ekonomi. Hasil penelitiannya membuktikan bahwa pelayanan perbankan seperti pemberian kredit bisa meningkatkan pertumbuhan ekonomi.

Pertumbuhan ekonomi Asia ternyata belum didukung oleh akses masyarakat terhadap lembaga keuangan. Akses masyarakat Indonesia terhadap lembaga keuangan juga masih rendah. Berdasarkan data dari World Bank, Global Financial Inclusion Index (2011) memaparkan bahwa Financial Inclusion Index Indonesia hanya 19.6 persen. Ini masih jauh di bawah negara-negara lain seperti Malaysia 66.7 persen, Philipina 26.5 persen, Thailand 77.7 persen, Vietnam 21.4 persen, India 35.2 persen, China 63.8 persen, Rusia 48.2 persen, dan Brazil 55.9 persen.

Masyarakat memiliki hambatan dalam mengakses lembaga keuangan. Tingginya unbankable people disebabkan karena gap kemiskinan antar provinsi, 
rendahnya pembiayaan UMKM, suku bunga kredit mikro tinggi, asymmetric information, kemampuan manajemen UMKM kurang memadai, monopoli bank pada sektor mikro, dan terbatasnya saluran distribusi jasa keuangan. Inilah yang menjadi alasan urgennya pengimplementasian financial inclusion.

Pada KTT Pittsburgh bulan September 2009, para pemimpin G20 berkomitmen untuk meningkatkan akses pelayanan keuangan bagi masyarakat miskin. Disini diluncurkan G20 Financial Inclusion Experts Group (FIEG) dan juga menyepakati model Small and Medium Sized Enterprise (SME) untuk mendapatkan akses pembiayaan dari perbankan, serta memperkuat regulasi financial inclusion dan perlindungan konsumen. Pada KTT Toronto bulan Juni 2010, para pemimpin G20 menegaskan kembali komitmen mereka untuk meningkatkan akses layanan keuangan bagi masyarakat miskin dan meluncurkan G20 SME finance challenge. Pada KTT Toronto sektor swasta juga dihimbau ikut andil dalam mewujudkan financial inclusion. Para pemimpin G20 juga mendukung satu prinsip Inklusi Keuangan Inovatif, yang bertujuan untuk membentuk landasan dan rencana aksi pragmatis untuk meningkatkan akses layanan keuangan bagi masyarakat miskin. Hasil kesepakatan dalam KTT negara G-20 menetapkan financial inclusion sebagai pilar penting dalam pembangunan ekonomi dan pengentasan kemiskinan di negara-negara anggotanya. Negara yang memiliki masalah terkait kemiskinan berupaya untuk menciptakan sistem keuangan yang inklusif. Hal ini menjadikan financial inclusion salah satu fokus pembangunan pada sektor keuangan di berbagai negara, karena sistem keuangan yang baik dapat mendorong pertumbuhan dan mengurangi kemiskinan.

Kamalesh Shailesh C. Chakrobarty (2011) mengatakan financial inclusion mempromosikan penghematan dan mengembangkan budaya menabung, meningkatkan akses kredit, baik kewirausahaan maupun konsumsi dan juga memungkinkan mekanisme pembayaran yang efisien, sehingga memperkuat basis sumber daya lembaga keuangan yang mampu memberikan manfaat ekonomi sebagai sumber daya dan tersedianya mekanisme pembayaran yang efisien dan alokatif. Bukti empiris menunjukkan bahwa negara-negara dengan populasi penduduk yang besar, belum mempunyai akses 
yang luas terhadap sektor formal lembaga keuangan dan juga menunjukkan rasio kemiskinan yang lebih tinggi dan ketimpangan yang lebih tinggi. Dengan demikian, financial inclusion hari ini bukanlah merupakan pilihan, tetapi menjadi sebuah keharusan dan perbankan merupakan pendorong utama untuk implementasi financial inclusion.

Demirguc-Kunt, et.al (2014) dalam penelitiaannya Islamic finance and financial inclusion: measuring use of and demand for formal financial services among Muslim adults menyatakan bahwa orang muslim lebih mungkin memiliki akun resmi di perbankan dibandingkan non-muslim. Dengan adanya instrumen-instrumen redistributif dalam ekonomi Islam, seperti zakat, infaq, s\}adaqah, maka orang muslim berpotensi besar dalam melakukan financial inclusion.

Franklin Allen, et.al (2012) dalam penelitiannya the foundations of financial inclusion: understanding ownership and use of formal accounts, menggunakan data 123 negara dan lebih dari 124.000 orang, menyatakan bahwa kebijakan-kebijakan yang dibuat oleh pihak-pihak yang berkepentingan, akan membantu dan mendorong masyarakat miskin untuk memiliki akses ke lembaga keuangan.

Mahmoud Mohieldin, et.al (2011) dalam penelitian the role of Islamic finance in enhancing financial inclusion in organization of Islamic cooperation (OIC) countries mengidentifikasi kesenjangan yang terjadi di negara-negara yang tergabung dalam Organisasi Kerjasama Islam (OKI). Kesenjangan ini terkait keuangan mikro syariah dan instrumen redistribusi tradisional. Penelitian ini menyimpulkan bahwa pengimplementasian instrumen ekonomi konvensional dapat menyebabkan kemiskinan dan ketidakmetaraan ekonomi di negara-negara muslim. Oleh karena itu, para pembuat kebijakan di negaranegara muslim yang serius dalam mengimplementasikan financial inclusion, harus memanfaatkan potensi instrumen syariah untuk mencapai tujuan dan fokus pada peningkatan infrastruktur, serta dukungan regulasi yang kuat. Instrumen syariah yang dimaksud adalah instrumen redistributif seperti zakat, shadaqah, wakaf, dan qard al-Hasan. 
Financial inclusion di Indonesia baru di luncurkan pada tahun 2010. Bank Indonesia meluncurkan program National Strategy for Financial Inclusion (NSFI) sebagai upaya untuk memperluas akses masyarakat terhadap jasa keuangan. Selama ini, 32\% atau 76 juta penduduk sama sekali belum tersentuh jasa keuangan (financial exclusion). Selain itu, 60-70\% Usaha Mikro, Kecil, dan Menengah (UMKM) juga belum memiliki akses terhadap perbankan. Padahal hampir 53 juta masyarakat miskin yang bekerja di sektor UMKM memiliki potensi yang sangat besar untuk menurunkan pengganguran dan mengurangi kemiskinan.

Implementasi financial inclusion di Indonesia sudah dilakukan dalam berbagai bentuk seperti pemberian Kredit Usaha Rakyat (KUR) dan pengembangan BMT (Baitul Mal wa al-tamwil). KUR adalah skema kredit usaha khusus bagi UMKM dan koperasi yang telah memenuhi standar kelayakan usaha namun tidak memiliki agunan sesuai dengan persyaratan yang ditetapkan oleh perbankan. Melalui program KUR pemerintah berupaya meningkatkan akses UMKM kepada kredit usaha dari perbankan dengan cara meningkatkan kapasitas perusahaan penjamin.

Program KUR secara resmi diluncurkan pada 5 november 2007. Peluncuran tersebut merupakan tindak lanjut penandatanganan Nota Kesepahaman Bersama (MoU) antara pemerintah dan dunia perbankan pada 9 Oktober 2007 tentang penjaminan kredit/pembiayaan kepada UMKM dan Koperasi. Terdapat tiga pilar utama dalam pelaksanaan program KUR, yaitu: (1) Pemerintah. Pemerintah dalam hal ini mendorong, membantu, dan mendukung penyaluran dan penjaminan kredit; (2) Lembaga Penjamin. Bertindak sebagai wakil pemerintah dan menjadi penjamin atas kredit yang disalurkan oleh perbankan; (3) Perbankan. Institusi perbankan bertindak selaku lembaga penerima jaminan, yang menyalurkan kredit kepada UMKM dan koperasi dengan menggunakan dana internal masing-masing.

Penelitian Otoritas Jasa keuangan (OJK) tahun 2013 melalui survei di 20 provinsi dengan 8.000 responden, mengungkap relatif rendahnya literasi (pemahaman) keuangan masyarakat Indonesia. Kondisi ini sejalan dengan rendahnya tingkat inklusi keuangan warga. Dalam hal literasi, tingkat 
pemahaman masyarakat atas perbankan sekitar 22 persen, jasa asuransi 18 persen, pegadaian 15 persen, lembaga pembiayaan 7 persen, dan pasar modal 4 persen. Hasil-hasil ini mengandung pesan bahwa tidak ada pilihan lain bagi bangsa Indonesia kecuali membuat program dan kebijakan untuk meningkatkan akses keuangan bagi masyarakat miskin, yakni program dan kebijakan yang dapat menjadi solusi bagi rumah tangga miskin yang kesulitan mendapatkan dukungan kredit dari lembaga keuangan formal.

Perbankan syariah juga merupakan lembaga penting dalam mengimplementasikan financial inclusion di Indonesia. Jika kita flashback ke 2008, jumlah pemain industri perbankan syariah saat itu masih berjumlah 155, yaitu 3 Bank Umum Syariah (BUS), 28 Unit Usaha Syariah (UUS), dan 124 Bank Pembiayaan Rakyat Syariah (BPRS). Kini jumlah itu semakin meningkat seiring bertambahnya kesadaran masyarakat untuk menggunakan produk-produk keuangan non-bunga. Pada Desember 2013 saja Indonesia telah memiliki 11 Bank Umum Syariah (BUS), 23 Unit Usaha Syariah (UUS), dan 16 Bank Pembiayaan Rakyat Syariah (BPRS). Ini merupakan bukti konkrit bahwa perbankan syariah mampu bertahan dan tumbuh meskipun di tengah instabilitas ekonomi, seperti krisis 1998, 2008 dan krisis yang melanda Eropa 2011 silam. Perkembangan secara kuantitas ini sudah tersebar dari pusat hingga ke daerah sehingga bisa dijangkau oleh semua lapisan masyarakat. Keberadaan perbankan syariah sebagai salah satu bagian penting dari lembaga keuangan formal di negeri ini diharapkan mampu mengimplementasikan financial inclusion.

\section{METODE}

Penelitian ini merupakan penelitian lapangan (field research) dengan pendekatan kuantitatif dan kualitatif (mixed method) menggunakan strategi eksploratoris sekuensial. John W. Creswell (2009) mengatakan strategi eksploratoris sekuensial melibatkan pengumpulan dan analisis data kualitatif pada tahap pertama, yang kemudian diikuti oleh pengumpulan dan analisis data kuantitatif pada tahap kedua berdasarkan hasil-hasil pada tahap pertama. 
Penulis menggunakan data primer dan data sekunder. Hendri Tanjung dan Abrista Devi (2013) mengatakan bahwa data yang sudah siap/dipublikasikan oleh instansi terkait dan langsung dapat dimanfaat oleh peneliti disebut data sekunder. Data yang belum tersedia dan untuk memperoleh data tersebut peneliti harus menggunakan beberapa instrument penelitian seperti kusioner, wawancara, observasi, dan sebagainya, maka dinamakan data primer.

Data primer yang penulis maksud adalah data hasil wawancara (interview). Menurut Lofland dan Lofland (2013) sumber data yang utama dalam penelitian kualitatif ialah kata-kata, dan tindakan, selebihnya adalah data tambahan berupa dokumen dan lain-lain. Data primer kualitatif umumnya berupa variasi-variasi persepsi bisa dari responden atau pelanggan. Wawancara langsung dilakukan kepada pihak perbankan Syariah.

Sumber sekunder berupa laporan keuangan Bank Umum Syariah selama lima tahun terakhir yaitu 2010-2014, sumber-sumber dari buku, jurnal, artikel, serta berbagai sumber lain yang berkaitan dengan penelitian penulis. Data sekunder digunakan untuk memperkuat data primer. Bank Umum syariah yang dimaksud adalah Bank Syariah Bukopin, Bank Syariah Mandiri, dan BRI Syariah.

Analisis data kualitatif menggunakan teknik analisis yang dikembangkan oleh Straruss dan Corbin (2007) dengan tiga langkah besar, yaitu (1) Open Coding, (2) Axial Coding, (3) Selective Coding. Open coding merupakan prosedur breaking down (merinci kelengkapan data), examining (memeriksa), comparing (membandingkan), conceptualizing (menjelaskan konsep lokal), categorizing (mengkategori data). Sedangkan pada tahap axial coding terdapat model grounded theory, yaitu kondisi penyebab $\rightarrow$ fenomena $\rightarrow$ konteks $\rightarrow$ kondisi pendukung dan penghambat $\rightarrow$ strategi interaksi dan tindakan $\rightarrow$ konsekuensi. Tahap terakhir adalah selective coding dan menghasilkan simpulan yang kemudian diangkat menjadi general design.

Kasmir (2014) mengatakan rasio keuangan digunakan untuk mengevaluasi kinerja dan kondisi keuangan perusahaan. Rasio keuangan akan memperlihatkan tingkat kesehatan suatu perusahaan/perbankan. Analisis rasio 
yang digunakan adalah Capital Adequacy Ratio (CAR), Return on Assets (ROA), Return on Equity (ROE), Non Performing Financing (NPF), Financing to Deposit Ratio (FDR), dan Biaya Operasional atas Pendapatan Operasional (BOPO).

\section{PEMBAHASAN}

Perbankan memiliki peran penting dalam pemberian akses kepada unbankable people. sektor perbankan Indonesia mengalami perkembangan dari tahun ke tahun. Hal ini dapat dilihat dari meningkatnya jumlah kantor cabang, Dana Pihak Ketiga (DPK) yang terhimpun, dan kredit yang disalurkan oleh perbankan. Seiring dengan perkembangan sektor perbankan, layanan jasa perbankan juga harus merata di seluruh Indonesia. Layanan perbankan harus menjangkau masyarakat di seluruh provinsi yang ada di Indonesia. Distribusi layanan perbankan ini dapat diukur dengan tingkat financial inclusion, baik di Indonesia secara keseluruhan ataupun per provinsi. Sistem keuangan yang semakin inklusif dapat mengalokasikan sumberdaya yang produktif semakin efisien, meningkatkan kemampuan masyarakat dalam mengelola keuangan, mengurangi pertumbuhan penyaluran kredit informal yang bersifat eksploitatif (kredit oleh rentenir).

\section{a. Funding in Islamic Banks}

Sebuah sistem keuangan yang inklusif harus memiliki pengguna sebanyak mungkin, oleh karena itu sistem keuangan yang inklusif harus menjangkau secara luas di antara pengguna. Proporsi dari populasi yang memiliki rekening bank merupakan sebuah ukuran untuk penetrasi perbankan. Data World Bank tahun 2010 menunjukkan bahwa dua pertiga masyarakat Indonesia sudah mempunyai simpanan. Lebih kurang 50 persen memiliki akun di lembaga keuangan formal. Mayoritas menabung di bank dan sangat sedikit yang menabung di koperasi dan lembaga keuangan mikro. Lebih kurang 18 persen punya simpanan di tempat lain seperti arisan dan lain-lain.

Ascarya (2007) mengatakan menabung di bank syariah bisa menjadi salah satu langkah perencanaan di masa depan. Produk-produk pendanaan/saving bank syariah ditujukan untuk memobilisasi dan investasi tabungan untuk pembangunan perekonomian dengan cara yang adil sehingga 
keuntungan yang adil dapat dijamin bagi semua pihak. Tujuan mobilisasi dana merupakan hal penting karena Islam secara tegas mengutuk penimbun tabungan dan menuntut penggunaan dana secara produktif dalam rangka mencapai tujuan sosial ekonomi Islam. Dalam hal ini, bank syariah melakukan tidak dengan prinsip bunga (riba), melainkan dengan prinsip yang sesuai dengan ajaran syariat Islam, terutama wadi'ah, qard, mudarobah, dan ijarah.

Komposisi Dana Pihak Ketiga (DPK) bank syariah di Indonesia berkembang pesat seiring dengan perkembangan bank syariah di Indonesia. Perkembangan signifikan pada DPK ini bisa juga dilihat secara BSM mengalami pertumbuhan DPK mencapai hampir 50\% mulai tahun 2010 sampai 2014, BSM juga menguasai hampir 40\% dari pangsa pasar DPK perbankan syariah Indonesia. Secara lebih rinci terlihat pada tabel di bawah ini.

Tabel 1. Perkembangan Dana Pihak Ketiga (DPK) Bank Syariah Mandiri (BSM) 2010-2014

\begin{tabular}{lrrrrr}
\hline \multicolumn{1}{c}{ Keterangan } & \multicolumn{1}{c}{$\mathbf{2 0 1 0}$} & \multicolumn{1}{c}{$\mathbf{2 0 1 1}$} & \multicolumn{1}{c}{$\mathbf{2 0 1 2}$} & \multicolumn{1}{c}{$\mathbf{2 0 1 3}$} & \multicolumn{1}{c}{$\mathbf{2 0 1 4}$} \\
\hline BSM & 29.000 & 42.620 & 47.410 & 56.461 & 59.821 \\
Pertumbuhan (\%) & 49,95 & 46,97 & 11,24 & 19,09 & 5,95 \\
Perbankan Syariah & 76.036 & 115.415 & 147.512 & 176.292 & 217.858 \\
Nasional $^{*}$ & & & & & \\
Pertumbuhan (\%) & 45,46 & 51,79 & 27,81 & 19,51 & 18,70 \\
Pangsa & 38,13 & 36,93 & 32,14 & 32,03 & 27,46 \\
\hline
\end{tabular}

Keterangan

*) Terdiri atas BUS dan UUS

Pangsa adalah DPK Bank Syariah Mandiri (BSM) dibanding DPK Perbankan Syariah

Miliar Rupiah (in Billion IDR)

Sumber: Annual Report 2010-2014 Bank Syariah Mandiri (BSM)

Bank syariah Bukopin (BSB) sebagai salah satu bagian dari bank umum syariah juga mengalami perkembangan yang cukup signifikan. BSB telah mengalami perkembangan pesat, salah satunya adalah pada Dana pihak ketiga (DPK). Penghimpunan DPK BSB tumbuh dari Rp 3,27 triliun pada 2013 menjadi Rp 3,99 triliun pada 2014. Sampai akhir 2013 naik sebesar Rp421,48 miliar atau tumbuh sebesar 14,78\%, menjadi sebesar Rp3,27 triliun pada 2013 dari Rp2,85 triliun pada 2012. Pertumbuhan DPK BSB pada 2010 sampai 2014 rata-rata 26\% bahkan lebih per tahun. Pertumbuhan DPK yang dihimpun BSB trennya positif dengan kenaikan secara nominal yang cukup signifikan. Secara lebih rinci bisa terlihat dari tabel di bawah ini. 
Tabel 2. Perkembangan Dana Pihak Ketiga PT Bank Syariah Bukopin 2010-2014

\begin{tabular}{|c|c|c|c|c|c|}
\hline Keterangan & 2010 & 2011 & 2012 & 2013 & 2014 \\
\hline Bank Syariah Bukopin & 1.622 & 2.292 & 2.851 & 3.272 & 3.995 \\
\hline Pertumbuhan (\%) & 27,52 & 41,30 & 24,39 & 14,78 & 22,09 \\
\hline $\begin{array}{l}\text { Perbankan Syariah } \\
\text { Nasional }^{*}\end{array}$ & 76.036 & 115.415 & 147.512 & 176.292 & 217.858 \\
\hline Pertumbuhan (\%) & 45,46 & 51,79 & 27,81 & 19,51 & 18,70 \\
\hline Pangsa & 2,13 & 1,99 & 1,93 & 1,86 & 1,83 \\
\hline
\end{tabular}

Keterangan

*) Terdiri atas BUS dan UUS

Pangsa adalah DPK PT. BSB disbanding DPK Perbankan Syariah

Miliar Rupiah (in Billion IDR)

Sumber: Annual Report 2013 PT. Bank Syariah Bukopin.

Di tengah peta persaingan perebutan dana yang semakin ketat, BSB masih mampu menjaga pangsanya tetap stabil sepanjang 2014. Sampai dengan Desember 2014, pangsa DPK BSB terhadap total DPK perbankan syariah mencapai 1,83\%. Sementara terhadap total DPK bank umum syariah yang mencapai Rp170,72 triliun, pangsa BSB mencapai 2,34\%. Ke depan, BSB akan terus berupaya meningkatkan pangsanya, terutama melalui peningkatan porsi dana murah, yakni giro dan tabungan. BRI syariah juga tumbuh signifikan, ratarata DPK BRI syariah tumbuh 66,6 persen setiap tahun sepanjang 2010 sampai 2014. DPK penghimpunan dana pihak ketiga tahun 2014 tumbuh 21,14\%, dari Rp13,8 triliun menjadi Rp16,7 triliun. Pada 2014 pangsa DPK BRI syariah mencapai 7,7\% dari pangsa DPK perbankan syariah nasional.

Tabel 3. Perkembangan Dana Pihak Ketiga (DPK) BRI syariah 2010-2014

\begin{tabular}{|c|c|c|c|c|c|}
\hline Keterangan & 2010 & 2011 & 2012 & 2013 & 2014 \\
\hline BRI syariah & $5.096,60$ & $9.906,41$ & $11.948,89$ & $13.794,87$ & $16.711,52$ \\
\hline Pertumbuhan (\%) & 181,53 & 94,37 & 20,61 & 15,44 & 21,14 \\
\hline $\begin{array}{l}\text { Perbankan Syariah } \\
\text { Nasional }^{*}\end{array}$ & 76.036 & 115.415 & 147.512 & 176.292 & 217.858 \\
\hline Pertumbuhan (\%) & 45,46 & 51,79 & 27,81 & 19,51 & 18,70 \\
\hline Pangsa & 6,7 & 8,6 & 8,1 & 7,8 & 7,7 \\
\hline $\begin{array}{l}\text { Keterangan } \\
\text { *) Terdiri atas BUS d } \\
\text { Pangsa adalah DPK B }\end{array}$ & $\begin{array}{l}\text { UUS } \\
\text { syariah di }\end{array}$ & banding DP & Perbankan & yariah & \\
\hline
\end{tabular}


Sebagai perbankan yang masih dalam tahap perkembangan, selama lima tahun terakhir yaitu tahun 2010 sampai 2014, bank syariah mengalami pertumbuhan yang signifikan pada sisi DPK. Pertumbuhan DPK perbanperbankan syariah tidak hanya dari sisi nominal tetapi juga jumlah nasabahnya. Data startistik perbankan syariah OJK mencatat bahwa jumlah nasabah DPK BUS dan UUS selalu mengalami kenaikan selama lima tahun terakhir, yaitu sebesar 6.053.658 tahun 2010, 8.187.428 tahun 2011, 10.847.862 tahun 2012, 12.727.187 tahun 2013, dan 14.444.146 tahun 2014. Jumlah ini akan terus mengalami perkembangan mengingat masyarakat Indonesia mayoritas adalah muslim.

\section{b. Financing in Islamic Banks}

Pembiayaan di perbankan syariah menggunakan akad mudarobah, akad musharakah, akad murabahah, akad salam, akad istisna, akad ijaroh, akad qard, dan akad lainnya. Data statistic Otoritas Jasa Keuangan (OJK) (2015) mencatat total pembiayaan selalu mengalami peningkatan setiap tahun, yaitu 50,56 persen tahun 2011, 43,69 persen tahun 2012, 24,82 persen tahun 2013, 7,17 persen tahun 2014, dan 0,69 persen terhitung maret tahun 2015 . Memang pada maret 2015 ini peningkatan komposisi pembiayaan perbankan syariah tergolong kecil diakibatkan melemahnya ekonomi nasional.

Secara spesifik perkembangan financing perbankan syariah bisa terlihat pada beberapa Bank Umum Syariah berikut. Pembiayaan BSM tumbuh signifikan pada lima tahun terakhir yaitu 2010-2015. Tahun 2010 mengalami kenaikan sebesar 44,39\%, tahun 2011 naik 53,23\%, tahun 2012 mengalami kenaikan 21,84, dan tahun 2013 naik 12,76\%, tahun 2014 memang sedikit mengalami pertumbuhan negatif sebesar 2,6\% disebabkan karena perlambatan ekonomi global. BSM menguasai pembiayaan dengan pangsa rata-rata 30,76 persen dibanding pembiayaan perbankan syariah nasional. Secara rinci bisa dilihat pada tabel di bawah ini. 
Tabel 4. Perkembangan Pembiayaan Bank Syariah Mandiri (BSM)

\begin{tabular}{lrrrrr}
\hline \multicolumn{1}{c}{ Keterangan } & \multicolumn{1}{c}{$\mathbf{2 0 1 0}$} & \multicolumn{1}{c}{$\mathbf{2 0 1 1}$} & \multicolumn{1}{c}{$\mathbf{2 0 1 2}$} & \multicolumn{1}{c}{$\mathbf{2 0 1 3}$} & \multicolumn{1}{c}{$\mathbf{2 0 1 4}$} \\
\hline BSM & 23.970 & 36.730 & 44.750 & 50.460 & 49.133 \\
Pertumbuhan (\%) & 44,39 & 53,23 & 21,84 & 12,76 & $-2,6$ \\
Perbankan Syariah & 68.181 & 102.655 & 147.505 & 180,833 & 199.330 \\
Nasional $^{*}$ & & & & & \\
Pertumbuhan (\%) & 45,42 & 50,56 & 43,69 & 22,59 & 8,26 \\
Pangsa (\%) & 35,16 & 35,78 & 30,34 & 27,90 & 24,65 \\
\hline
\end{tabular}

Keterangan

${ }^{*}$ ) Terdiri atas BUS dan UUS

Pangsa adalah Pembiayaan Bank Syariah Mandiri (BSM) dibanding Pembiayaan

Perbankan Syariah

Miliar Rupiah (in Billion IDR)

Sumber: Annual Report 2013 Bank Syariah Mandiri (BSM)

Meskipun tantangan dalam penyaluran pembiayaan yang dihadapi BSB, baik dari sisi eksternal secara global maupun dari dalam negeri sepanjang 2013 cukup berat, secara umum BSB dapat menghadapi tantangan tersebut dengan cukup baik. Sampai akhir 2013, total pembiayaan yang disalurkan BSB mengalami pertumbuhan 25,16\%. Total pembiayaan yang disalurkan BSB pada 2013 mencapai Rp 3,28 triliun, naik Rp 659,63 miliar dari 2012. Pertumbuhan tersebut melampaui pertumbuhan industri perbankan syariah nasional yang hanya sebesar 22,59\%. Tahun 2014 pembiayaan BSB juga mengalami kenaikan sebesar $13,07 \%$.

Sama halnya dengan BSM dan BSB, BRI syariah juga mengalami peningkatan pada pembiayaan. Pembiayaan BRI syariah tumbuh rata-rata 47,57\% setiap tahun sepanjang 2010 sampai 2014. BRI syariah menguasai pangsa 7,9\% pada 2014 dibanding pembiayaan bank syariah nasional. Secara lebih rinci bisa terlihat pada Tabel 6. Kebanyakan bank umum syariah punya produk sendiri terkait pembiayaan terhadap usaha mikro, kecil, dan menengah (UMKM), seperti Bank Syariah Mandiri (BSM) dengan warung mikronya, BRI syariah dengan mikro 25, Bank syariah Bukopin dengan mikro 25 nya, dan lainlain. 
Tabel 5. Perkembangan Pembiayaan PT Bank Syariah Bukopin 2010-2014

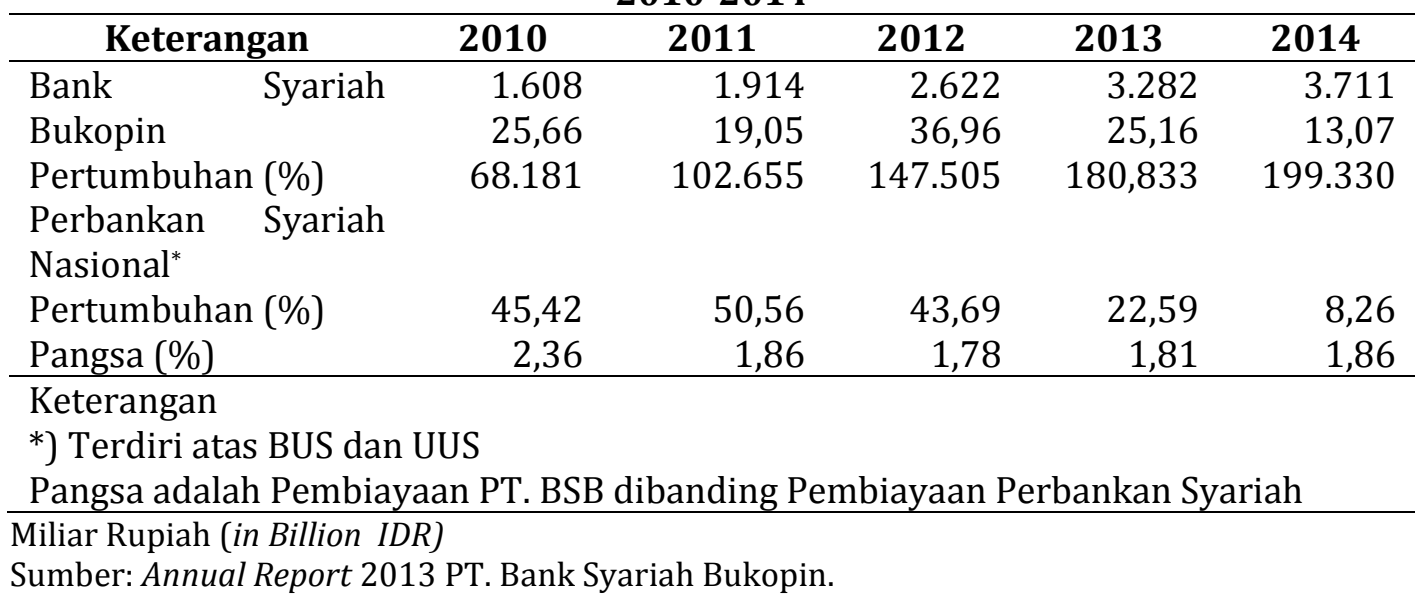

Dalam rangka mendorong pertumbuhan ekonomi di sektor riil dan membantu program pemerintah dalam penyerapan tenaga kerja, BSM memiliki komitmen untuk menyalurkan pembiayaan bagi usaha kecil dan mikro. Taufik Machrus, Culture and Customer Care Group Head BSM (2015) Bank Syariah Mandiri (BSM) melalui warung mikronya menawarkan pembiayaan mudah dan cepat kepada masyarakat. Pembiayaan multiguna dengan limit 11 juta rupiah sampai 200 juta rupiah. Pembiayaan ini menggunakan akad murobahah, dimana nasabah diberi kemudahan pada prosedur dan mekanisme pembiayaan.

Tabel 6. Perkembangan Pembiayaan BRI syariah 2010-2014

\begin{tabular}{|c|c|c|c|c|c|}
\hline Keterangan & 2010 & 2011 & 2012 & 2013 & 2014 \\
\hline BRI syariah & $5.527,08$ & $9.170,30$ & 11.403 & $14.167,36$ & $15.691,43$ \\
\hline Pertumbuhan (\%) & 112,57 & 65,92 & 24,35 & 24,24 & 10,76 \\
\hline Perbankan & 68.181 & 102.655 & 147.505 & 180.833 & 199.330 \\
\hline Syariah Nasional ${ }^{*}$ & 45,42 & 50,56 & 43,69 & 22,59 & 8,26 \\
\hline Pertumbuhan (\%) & 8,1 & 8,9 & 7,7 & 7,8 & 7,9 \\
\hline \multicolumn{6}{|l|}{ Pangsa } \\
\hline \multicolumn{6}{|c|}{ Keterangan } \\
\hline \multicolumn{6}{|c|}{ *) Terdiri atas BUS dan UUS } \\
\hline \multicolumn{6}{|c|}{$\begin{array}{l}\text { Pangsa adalah Pembiayaan BRI syariah dibanding Pembiayaan Perbankan } \\
\text { Syariah }\end{array}$} \\
\hline
\end{tabular}

Pentingnya memberdayakan usaha kecil merupakan tantangan sekaligus peluang untuk meningkatkan portofolio pembiayaan di segmen tersebut. Pada 2014, BSM telah berhasil menyalurkan pembiayaan usaha mikro 
dan kecil sebesar Rp8,54 triliun atau 99,08\% terhadap jumlah penyaluran pembiayaan usaha mikro dan kecil pada 2013 sebesar Rp8,62 triliun. Pembiayaan terhadap sektor usaha mikro dan kecil memiliki makna yangpenting bagi BSM dalam kontribusi membangun negeri melalui peningkatan pemberdayaan masyarakat. Salah satu bentuk pembiayaan pada sektor usaha mikro dan kecil yang telah dilakukan Bank adalah BSM Pembiayaan Warung Mikro.

Warung Mikro BSM adalah layanan pembiayaan di kantor cabang dan cabang pembantu untuk nasabah kategori mikro. Plafon maksimum yang diberikan kepada nasabah melalui warung mikro BSM adalah Rp200 juta sesuai dengan rata-rata maksimum kebutuhan usaha mikro saat ini. Sampai dengan akhir 2014, outlet Warung Mikro yang telah dibuka berjumlah 456 outlet dan 30 Unit Kantor Area Mikro tersebar di seluruh wilayah Indonesia. BSM menyalurkan pembiayaan melalui warung mikro selama 2014 mencapai Rp2,02 triliun, tumbuh sebesar sebesar Rp92,7 miliar terhadap pembiayaan warung mikro pada 2013 sebesar Rp1,93 triliun.

Pada sektor pembiayaan mikro, BSM telah berhasil menyalurkan pembiayaan usaha mikro dan kecil sebesar Rp8,54 triliun atau 99,08\% terhadap jumlah penyaluran pembiayaan usaha mikro dan kecil pada 2013 sebesar Rp8,62 triliun. Pembiayaan terhadap sektor usaha mikro dan kecil memiliki makna yang penting bagi BSM dalam kontribusi membangun negeri melalui peningkatan pemberdayaan masyarakat. Salah satu bentuk pembiayaan pada sektor usaha mikro dan kecil yang telah dilakukan Bank adalah BSM Pembiayaan Warung Mikro.

Bank syariah tidak hanya bergerak sebagai comercial bank, tetapi juga social bank. Maka bank syariah menyadari peran penting sektor UMKM dalam menyokong perekonomian nasional. Bank syariah juga memberikan pembiayaan pada sektor UMKM. Bahkan kata Bapak Azhar Syarief (2015), Learning and Culture Manager BRI Syariah, pembiayaan mikro merupakan pembiayaan yang memiliki prospek besar sehingga banyak perbankan saat ini melirik sektor ini. 
Saat ini, Bisnis Mikro fokus secara konsisten pada aspek pembiayaan produktif. Sasaran nasabah pembiayaan adalah pedagang kebutuhan pokok dan pakaia n serta barang dagangan lainnya, dengan program "Serbu Pasar \& Open Table",yang masing-masing telah menyerap sekitar75\% dan 25\% dari total pembiayaan mikro yang disalurkan. Perusahaan memiliki tiga skema pembiayaan untuk melayani segmen mikro, yakni Mikro 25, Mikro 75 dan Mikro 500 Sesuai dengan nama yang diberikan, Mikro 25 adalah produk pembiayaan yang memiliki plafon sampai dengan Rp25 juta, begitu pun seterusnya. Pada tahun 2014, fokus plafond pembiayaan berada pada kisaran Rp5 juta - Rp300 juta.

Pada tahun 2014, total pembiayaan mikro yang disalurkan meningkat sebesar 31\% dari Rp2,455 triliun pada tahun 2013 menjadi Rp3,210 triliun pada tahun 2014, setelah sebelumnya juga mengalami peningkatan berturutturut selama 4 tahun. Pencapaian target pembiayaan ditahun 2014 dapat melampaui target Perjanjian Rencana Bisnis Bank (RBB) 2014 sebesar 109\%. Dari sisi tingkat kesehatan aset, tingkat NPF (Non Performing Financing) segmen mikro berhasil dijaga dikisaran angka 2,4\%, dengan Repayment Rate (tingkat kelancaran pembayaran angsuran) masih diangka 95,3\%.

Azhar Syarief, Learning and Culture Manager BRI Syariah (2015) menjelaskan trend Non Performing Financing (NPF) pembiayaan mikro BRI syariah minor, bahkan pada tahun 2012-2013 NPF BRI syariah mencapai 0\%. Hal ini disebabkan karena BRI Syariah punya relationship officer yang bertugas memberikan maintenance nasabah. Perbankan melakukan pertemuan sebulan sekali dengan nasabah untuk mengingatkan angsuran, diadakan pengajian, silaturahmi, dan lainnya. Mereka yang unbankable diajarkan cara mengelola uang dengan menggunakan amplop merah dan amplop putih. Amplop merah untuk membayar cicilan ke bank dan amplop putih untuk diputarkan kembali sebagai modal usaha. Nasabah juga diajarkan cara membuat laporan keuangan sederhana. Pembiayaan mikro BRI syariah terus tumbuh secara signifikan menjadi salah satu pilar pertumbuhan bisnis. Sejumlah 291 outlet unit mikro syariah mengelola 27.924 rekening nasabah. 
Bank Syariah Bukopin memiliki iB Pinjaman Qardh Adalah pinjam meminjam dana tanpa imbalan dengan kewajiban pihak peminjam mengembalikan pokok pinjaman secara sekaligus atau cicilan dalam jangka waktu tertentu dan pembiayaan lainnya. Secara keseluruhan, pembiayaan yang disalurkan BSB sepanjang 2013 berada pada tren positif. Berdasarkan jenisnya, kontribusi pembiayaan modal kerja, investasi, dan konsumsi terhadap total pembiayaan BSB pada 2013 masing-masing mencapai 30,68\%; 31,43\%; $37,89 \%$. Pembiayaan konsumsi mengalami pertumbuhan tertinggi yaitu sebesar $63,69 \%$.

Pembiayaan UMKM kepada pihak ketiga bukan bank sepanjang 2013 masih sangat dominan jika dibandingkan dengan pembiayaan non UMKM. Sejalan dengan fokus bisnis pembiayaan BSB pada pembiayaan di sektor UMKM, ada 9 segmen bisnis utama yang disasar BSB, yaitu telekomunikasi, pendidikan, kesehatan, minyak dan gas, transportasi, jasa pariwisata dan perhotelan, properti dan konstruksi, perdagangan umum, lembaga keuangan dan multifinance yang dilakukan secara selektif dan pruden.

\section{c. Analisis rasio perbankan syariah}

James C Van Horne (2014) sebagaimana yang dikutip oleh Kasmir mengatakan bahwa rasio keuangan merupakan indeks yang menghubungkan dua angka akuntansi dan diperoleh dengan membagi satu angka dengan angka lainnya. Rasio keuangan digunakan untuk mengevaluasi kinerja dan kondisi keuangan perusahaan. Rasio keuangan akan memperlihatkan tingkat kesehatan suatu perusahaan/perbankan. Jadi rasio keuangan merupakan kegiatan membandingkan angka-angka yang ada dalam laporan keuangan dengan cara membagi satu angka dengan angka lainnya, sehingga akan terlihat perkembangan dan kesehatan bank.

'Imad A. Salman (2013) mengatakan bahwa analisis rasio penting digunakan untuk melihat tingkat kesehatan bank. profitabilitas sebagai salah satu tujuan bank komersil bisa diidentifikasi faktor-faktor kunci yang mempengaruhinya dengan menggunakan analisis rasio keuangan, seperti pengaruh kas, asset, likuiditas, ekuitas, dan lainnya. Bank sebagai salah satu sumber modal bagi masyarakat dalam rangka menggerakkan perekonomian, 
maka perlu kajian khusus terkait kinerja perbankan dengan menggunakan analisis rasio, agar perbankan berefek positif pada perekonomian.

Perkembangan di bidang kelembagaan di bidang perbankan syariah, juga diikuti dengan capaian kinerja yang baik oleh perbankan syariah. Fungsi intermediari perbankanpun juga berjalan dengan maksimal jika dilihat dari besarnya pembiayaan yang diberikan dibandingkan dari dana pihak ketiga yang mencapai 90\% bahkan lebih. Selain itu perbankan syariah juga terbukti mampu menjaga kualitas pembiayaan yang diberikan sehingga non performing financing (NPF) nya relatif rendah dibandingkan NPL perbankan nasional.

Pertumbuhan positif yang dicapai perbankan syariah dari sisi penghimpunan dana, pembiayaan,maupun pencapaian laba bersih, didukung dengan membaiknya indikator keuangan utama. Rasio kecukupan modal minimum atau capital adequacy ratio (CAR) maupun rasio return on assets (ROA) dan return on Equity (ROE) masih berada pada batas ketentuan yang berlaku.

Otoritas Jasa Keuangan (OJK) (2015) mencatat Sepanjang 6 tahun terakhir, CAR bank syariah berada pada batas aman. Tercatat rasio CAR perbankan syariah sejak tahun 2010 sampai maret 2015 adalah 16,25\%, $16,63 \%, 14,13 \%, 14,42 \%, 15,74 \%, 13,85 \%$. Ini masih di atas batas minimum ketentuan Bank Indonesia sebesar 8\%. Rasio Return on Assets (ROA) bank syariah juga mengalami kenaikan pada beberapa tahun terakhir, yaitu 1,67\% tahun 2010, 1,79\% tahun 2011, 2,14\% tahun 2012, 2,00\% tahun 2013, 0,85\% tahun 2014, dan 1,13\% per maret 2015. Meskipun terjadi penurunan pada tahun 2014, tetapi meskipun demikian bank syariah masih tetap bisa menghasilkan laba dari asset yang dimilikinya. Kenaikan ROA juga diikuti dengan kenaikan return on Equity (ROE). Tercatat 17,58\% tahun 2010, 15,73 tahun 2011, 24, 06 tahun 2012, 17, 24\% tahun 2013, 5,85\% tahun 2014, dan 8,91\% per maret 2015. Hal ini mengindikasikan kemampuan manajemen dalam menghasilkan laba bagi perusahaan melalui asset yang dimiliki. 
Bank syariah juga mampu menjaga kualitas pembiayaannya, terbukti sejak 2010 Non Performing Financing (NPF) nya relatif rendah yaitu 3,02\% tahun $2010,2,52 \%$ tahun $2011,2,22 \%$ tahun $2012,2,62 \%$ tahun $2013,4,33 \%$ tahun 2014 , dan $4,81 \%$ per maret 2015. Ini relatif rendah dibandingkan NPL perbankan nasional.

Posisi Financing to Deposit Ratio (FDR) perbankan syariah sangat baik, yaitu $89,67 \%$ tahun $2010,88,94 \%$ tahun $2011,100,00 \%$ tahun $2012,10,32 \%$ tahun 2013, 91,50\% tahun 2014, dan 94,24\% per maret 2015. Bank syariah mampu menjaga level FDR pada rentang 78\% sampai 100\% sebagaimana yang diharapkan regulator BI. Hal ini membuktikan bahwa bank syariah mampu menjalankan fungsinya sebagai lembaga intermediari dengan baik. Dana pihak Ketiga (DPK) tidak dibiarkan idle, tetapi benar-benar disalurkan pada sektor riil. BOPO atau perbandingan beban operasional terhadap pendapatan operasional bank syariah memang terbilang masih agak tinggi. Hal ini wajar karena sebagai perbankan yang masih terus berkembang, bank syariah gencar melakukan ekspansi guna pencapaian target bisnis.

\section{SIMPULAN}

Berdasarkan hasil analisis peran perbankan syariah dalam mengimplementasikan financial inclusion di Indonesia, dapat ditarik kesimpulan bahwa pertumbuhan perbankan syariah terlihat dari peningkatan aset, Dana Pihak Ketiga (DPK) naik 15\% sampai 45\% per tahun, pembiayaan juga mengalami kenaikan yang signifikan mencapai 50,05\% per tahun. Analisis rasio keuangan juga tercatat baik. Rasio pembiayaan terhadap DPK (FDR) perbankan syariah juga sangat baik berada pada batas yang ditetapkan BI yaitu 87\%-100\%. Kecukupan modal minimum perbankan syariah (CAR) cukup baik yaitu 15\% bahkan lebih. Tingkat income yang dihasilkan dari asset dan ekuitas juga cukup baik (ROA/ROE). Angka pembiayaan bermasalah rendah yaitu di bawah 5\%, bahkan di pembiayaan mikro bank syariah pernah mencapai NPF 0\%. Beban operasional atas pendapatan operasional (BOPO) memang masih tergolong tinggi karena perbankan syariah gencar melakukan ekspansi ke berbagai wilayah di Indonesia. Pertumbuhan yang dialami perbankan syariah ini sejalan dengan pertumbuhan ekonomi riil. 
Hasil analisis perbandingan antar laporan keuangan dan analisis rasio mengindikasikan bahwa kinerja dan kondisi keuangan perbankan syariah baik. Hal ini menjadikan perbankan syariah mampu menjadi garda depan pengimplementasian financial inclusion di Indonesia. pengimplementasian financial inclusion melalui perbankan syariah juga akan didukung oleh produkproduk perbankan syariah yang melakukan operasional berdasarkan prinsip Islam dan mengemban misi sosial kemasyarakatan.

\section{PUSTAKA ACUAN}

Ascarya. 2007. Akad \& Produk Bank Syariah. Jakarta: PT. Raja Grafindo Persada.

Basrowi \& Suwandi. 2008. Memahami Penelitian Kualitatif. Jakarta: Rineka Cipta.

Chapra, U. 2001. The Future of Economics: an Islamic Perspective. Jakarta: Gema Insani Press.

Chapra, U. 2000. Islam dan Pembangunan Ekonomi. Jakarta: Gema Insani Press. Chaudry, M.S. 2012. Sistem Ekonomi Islam: Prinsip Dasar, terj. Suherman Rosyidi. Jakarta: Kencana.

Choudhury, M.A. 1986. Contributions to Islamic Economic Theory. New York: St. Martin's Press, Inc.

Creswell, J.W. 2012. Research Design Pendekatan Kuallitatif, Kuantitatif, dan Mixed. Yogyakarta: Pustaka Pelajar.

Faiz, A \& O. Noviandi. 2009. Menyongsong Sistem Ekonomi anti Krisis. Bogor: Pustaka Thariqul Izzah, 2009.

Kahf, M. 1955. Ekonomi Islam, Telaah Analitik Terhadap Fungsi Sistem Ekonomi Islam. Yogyakarta: Pustaka pelajar.

Khan, M.A. 1994. An Introduction to Islamic Economics. Kuala Lumpur: percetakan Zafar SDN BHD.

Maleong, L.J. 2007. Metodologi Penelitian Kualitatif. Edisi Revisi. Bandung: PT. Remaja Rosdakarya.

Singarimbun, M. \& S. Effendi. 2008. Metodologi Penelitian Survei. Jakarta: Pustaka LP3ES.

Sjahdeini, S.R. 2010. Perbankan Syariah: Produk-produk dan Aspek-aspek Hukumnya. Jakarta: PT. Jayakarta Agung Offset. 
Sugiyono. 2009. Metode Penelitian Kuantitatif, Kualitatif, dan R\&D. Bandung: Alfabeta.

Wahid, N. 2014. Keuangan Inklusif Membongkar Hegemoni Keuangan. Jakarta: Gramedia.

Yunus , M. 2007. Bank Kaum Miskin, terj. Irfan Nasution. Prancis: CV Marjin Kiri. 